\title{
PATENA PRZY UDZIELANIU KOMUNII ŚW.
}

Zgodnie z Instrukcją św. Kongregacji dla Sakramentów z dnia 26 marca 1929 roku, która została zatwierdzona przez papieża Piusa XI, przy udzielaniu Komunii św., wiernym, oprócz białego obrusa, przepisanego rubrykami mszału, rytuału i ceremoniału biskupiego, należy używać także tzw. pateny komunijnej ${ }^{1}$ ).

W myśl powyższej Instrukcji wierni przyjmujący Komunię św., sami sobie podtrzymują patenę pod podbródkiem, i po jej przyjęciu, podają następnej osobie, począwszy od strony lekcji w stronę ewangelii.

Kapłan winien jednak czuwać nad.tym by pateny nie przechylano, nie odwracano itd., by w ten sposób zabezpieczyć partykuły znajdujące się na patenie przed zniszczeniem.

Ostatni, w rzędzie, z komunikujących, po przyjęciu Komunii św., patenę podaje kapłanowi, który przenosi ją następnie na stronę lekcji do następnego rzędu komunikujących, a po wykomunikowaniu wszystkich, także kapłan przenosi patenę do ołtarza.

Inaczej przedstawia się nieco sprawa przenoszenia pateny i podtrzymywanie jej przed komunikującymi, gdy Komunii św., udziela biskup (w pontyfikaliach), lub udzielana jest w czasie Mszy św. uroczystej z udziałem diakona lub innego kapłana, który wówczas podtrzymuje patenę.

Jeżeli Komunia św., była udzielana w czasie Mszy św. zbiera się starannie wszystkie cząsteczki eucharystyczne z pateny do kielicha mszalnego, a w przeciwnym razie do puszki ${ }^{2}$ ).

1) Por. Ephemerides Liturgicae 44 (1930) 73: ,...patina est alhibenda, argento aut metallo inaurato confecta, nullimode tamen artificiosa arte intus exculpta (ut facile sacra fragmenta colligantur)..."

$\left.{ }^{2}\right)$ Tamże: „Cropuscula vero, quae post Communionem distributam in patina forte extabunt quaeque haud clare esse sacrae Hostiae fragmenta, cum oliunde, ex. gr. ex capitibus vel vestibus communicantium provenire possint, non in calicem neque in pyxidem iniicientur, ne nausea fiat ipsi sacerdoti celebranti vel alteri sacerdoti qui suo tempore pyxidem purificabit, sed potius immitentur in vasculum super altare positum ad abluendos digitos".

„Quando Communio in leprosorum hospitiis distribuitur sive intrasive extra Missam, necessarium non est ut sacerdos sacrae Hostiae frag- 
Po dokładnym zebraniu wszystkich dostrzegalnych partykuł eucharystycznych, umieszcza się patenę komunijną w specjalnej bursie, znajdującej się obok tabernakulum, ale nie w tabernakulum.

Zamiast pateny komunijnej nie można dawać do rąk komunikujących wiernych (laików), pateny konsekrowanej, używanej do Mszy św., w myśl kan. 1306.

Poza tym kapłan udzielający Komunii św. nie może sam podtrzymywać równocześnie patenę, trzymając np. w ręce lewej puszkę i patenę $z$ odpowiednio przystosowanym uchwytem ${ }^{3}$ ).

Wreszcie na ,zakończenie należy dodać, iż gdyby ze względu na warunki miejscowe zdâwałoby się być rzeczą odpowiedniejszą, by patenę komunijną trzymał ministrant, możliwa jest taka praktyka, jak to wynika $\mathrm{z}$ odpowiedzi św. Kongregacji dla Sakramentów ${ }^{4}$ ), z dnia 28 października 1930 roku.

Kraków

Ks. TADEUSZ SZWAGRZYK

menta in patina extantia, quae forte labia et salivan leprosorum tetigerint, in calicem vel in pyxilem immittat, ob periculum morbi contagiosi contrahendi, sed hoc in casu paretur super altare vasculum cum aqua et stuppa seu gossypio, in quod vasculum purificatio patinae immitatur, eaque, quamprimum fieri poterit, in sacrarium iniiciatur (SRC 19 februaii 1909, Ephem. Liturg., an. 1909, 229-231)“.

3) SRC 12 augusti 1854, ad 21.

4) „Dubio Sacra Congregatio respondit quod usus ut patina apponatur, sub mento fidelium ab Acolytho seu missae inserviente nullimode prohibetur ab Instructione huius S. Congregationis "Dominus Salvator « dummodo tamen hic in usu patinae requisitam servet diligentiam eandem sursum ac decorsum non flectens ne fragmeta disperdantur". Ta sama Kongregacja 23 stycznia 1931. „Quo facilior autem fieret patinae usus, haec S. Congregatio non semel declaravit, eius menti esse conforme pisam patinam porrigi et supter mentum fidelium poni a clerico seu acolytho sacerloti inserviente". 